Original Research Paper

\title{
Gender Tendency of Russian Political Activity from the Perspective of Jurisprudence
}

\author{
Nadezhda N. Tarusina and Elena A. Isaeva \\ Faculty of Law, P.G. Demidov Yaroslavl State University, Yaroslavl, Russian Federation
}

Article history

Received: 21-08-2014

Revised: 11-10-2014

Accepted: 26-12-2014

Corresponding Author: Nadezhda N. Tarusina, Faculty of Law, P.G. Demidov Yaroslavl State University, Yaroslavl, Russian Federation E-mail: alexander.galushkin@yandex.ru

\section{Iintroduction}

Political (authoritative in a wide sense) management is a typical pattern of the gender situation and gender system (Connel, 1987) of the Russian society.

Even in contemporary (period of perestroika and post-perestroika) Russian political game machismo prevails undoubtedly.

It goes without saying that as elsewhere (including the Western world) the given situation has always been the result of patriarchal context of the history of gender roles.

In spite of the fact that it is possible for women to rival men, the former have to compete on the terms that have already been created by the latter ones.

This fact makes women adapt on the men's "territory" which is impregnated with machismo and methodology (Bryson, 2007).

United Nations Experts claim that legislators won't deal with the problems of children and $30 \%$ of deputies won't be worried with the special needs of the "second sex" unless the number of female deputies comes up to at least 20\% (Golod, 2008).

Despite some prejudices concerning the ability of women's elite with mandates of a deputy to speak for all social women's groups, the experience of the last two decades mainly proves that the more women are elected for political capacities the broader are the interests which they represent and protect during policymaking (Simone de Beauvoir, 1949).

In quite a number of countries with mature democracy where women at the expense of quotas have won $40-50 \%$ of positions in all power structures, they have changed the content of politics so that now it lays special emphasis on the sphere of daily living (healthcare, education, family support, pension system etc).

Meanwhile during the last decades gender quotas as a mechanism of gender equating have become common in legislation of a great number of states. However the problem of the impact which quotas make on women's representation remains acute up to now (Bryson, 2007). 
In $201181 \%$ of parliamentarians in the world were men. The same year in spring 52 countries have vested gender quotas in election legislation. In about 40 countries certain political parties have passed gender quotas as to their party list (Rainbow, 2010).

Gender quotas have become a kind of an obvious answer to the challenging question of low women's representation in political life.

However the data spread is evident. Thus in northern countries women take about $42,3 \%$ of positions in legislative bodies, in the countries of the Pacific Region it is only $12,9 \%$.

The average meaning is growing: In 1990-s women's representation was $14,6 \%$ for Lower chambers and 9, 4\% for Upper chambers. In 2010-s these rates went up to 19, 3 and $18,2 \%$ (Franceschet et al., 2012).

According to United Nations' attitude these days only parity participation of men and women in political authority structures secures balanced decision-making and provides stable development of a state.

What is the past and present situation of the Russian political management and political activity of citizens in the gender context?

Thus gender structure of the Supreme Soviet of the USSR made quite favorable outward impression (1952$26 \%, 1970-31 \%)$; in the local government the rates varied from 30 to $45 \%$ (in $1971-45,8 \%$ ).

Women joined these structures according to a special quota on the basis of unanimous vote. But during preperestroika (and partially perestroika) period the real power belonged to the Communist Party of the Soviet Union (article №5 of the constitution of the USSR of 1936).

The composition of this single party contained 79 , $1 \%$ of men and 20, 9\% of women, The Central Committee numbered respectively 97,2 and $2,8 \%$, the Politburo was made up of $100 \%$ of men.

The world of politics remained "masculine" whereas women were its object rather than subject. At the height of perestroika the quota system of women's representation was rejected.

Some political scientists and sociologists suppose that this happened when parliament began to play an active role in governance and policymaking of the state (Georgina, 2013).

Others claim that it was an attempt to substitute quota system to the real integration of women into the political process (Loshakova, 2013).

This hypothesis turned to be utopian; in 1989 the rate of women's representation halved $(16 \%)$, in 1990 it fell to $5,6 \%$, in the first years of sovereign Russia it came to $9,7 \%$ (1996-1999) and 7,6\% (1999-2003) (Ayvazova, 2004).

\section{Materials and Methods}

In the present article authors present summery of conducted research, where research problem was formulated, a good empirical base accumulate, an opportunity to focus on the research process and to draw conclusions that would reflect the real situation in the best possible way using: Introductionhypothesis, deduction-predictions, observation-nest of predictions, etc. was given.

\section{Results}

In 2003 the State Duma of the Russian federation passed a bill "on the state guarantee of equal treatment of men and women and equal opportunities for their realization'.

The bill creates some arrangements on provision of equal opportunities in case of implementation of eligibility (gender quotas), there is a clause on priority right for replacement of vacant government positions by a person of a sex that constitutes the minority at the given position or government service (article 3), organization of the Constitutional Court, The Supreme Court of Arbitration of the Russian Federation and auditors of the Chamber of Accounts based on the principle of gender equality (article 19).

However the draft was set by for almost a decade and only in 2011 the work over it was resumed. It can be likely supposed that there is a relationship between a sudden deputy's interest towards this draft and establishment of the international organization called "United Nations Women" exactly in 2011 which is headed by the former president of Chile Michelle Bachelet.

The draft is considered to be the most ambitious initiative of the UN aimed at the achievement of gender equality including development and elaborate integration of certain measures that are to improve the situation of women's political leadership.

\section{Discussion}

In recent years quantitative (and partly qualitative) indices in the given sphere have somewhat improved. The 6th State Duma contains 13,5\% of women; one woman out of eight has the position of the Vice President at the Lower house of the Russian parliament; 4 women are at the head of the Duma committees (on the issues of family, women and children; housing policies and communal services; security and anticorruption; financial market).

There are 13 women in the Federation Council which is also headed by a woman. In 2011-2012 during the debates concerning the principles of formation of houses there was a discussion over the idea related to the institution of equal gender representation (one man and one woman for a region). However it didn't attain the majority of votes.

One of possible reasons is that the Russian provinces don't still possess a competitive body of highly qualitative political female leaders whose increase in number isn't stimulated or promoted. Nevertheless in the 
first place the most obvious reason is the conserved patriarchal character of the Russian politics (Gender Issues in Russia, 2004).

Several women are the leaders of either the executive power of the region (3 constituent entities of the RF are governed by "the second sex") or legislative assemblies (7 women). Since 2012 two women have become members of the parliament of the Russian Federation; in 2013 women became the leaders of the Central Bank of The Russian Federation and the Accounts Chamber.

In 2014 a woman is also recommended at the position of ombudsman. (According to a witty remark of an experienced stateswoman if a female wants to be considered a notable figure in politics she "must work like a horse and behave like a lady").

In the regional Public chambers which are notable for civil activity, women's membership varies from 20 to $52 \%$. For example, in the Public chamber of Vladimir region the women's membership is 22 out of $42(52 \%)$, in Yaroslavl region-20 out of $80(25 \%)$, in Moscow region- 8 out of $43(18,6 \%)$, Chechen Republic-9 out of $36(25 \%)$ etc. According to this characteristic, the Federal Public chamber is at the bottom line-21\%. Only 17 women (about 20\%) are at the top of public chambers in the Russian regions.

Despite the declaration of the principle of equal opportunities for both men and women to participate in political activity that is specially set in the federal law (Sangadzhiev et al., 2013) "On political parties" (article 8 ), it is evident that for the most part these consolidations also follow the established tradition.

They don't pay proper attention to recommendation given by the Parliamentary Assembly of the Council of Europe (PACE) titled as "Electoral system as an instrument for increasing women's representation in politics" on indispensable gender quota system (not less that 40\%) and strict abidance of priority in the list of candidates by means of interchange of men and women.

One of the results of such inaction is the quantity of deputy portfolios: From $18 \%$ in the United Russia fraction to $4,3 \%$ in the communist party. It should be noted that quota system as a measure of gender equating doesn't always lead to definitely positive results.

Sometimes reverse discrimination attains a deformed character that at present is confirmed by European judicial practice (Tarusina, 2014).

The doctrine gives some suppositions that gender structure of the political management and also women's participation in the Russian political history as a whole are influenced by other diverse factors which affect all (or almost all) range of gender context of social life: Marginal condition of gendered discourse in the hierarchy of discourses; the authority's interest in conservation of the traditional gender roles, promotion of ideas of special woman's predestination and womanliness (that on the whole can't be denied-the problem is exactly in accents); evident or concealed discredit of a feminist (that is opposed to certain examples of female public figures who are not alien of feministic ideas); development of the discourse about hidden matriarchal character of the Russian society ("behind every great man there's a great woman") etc.

However conflict of interests and actions is an inevitable part of the existing system of people's rights and freedoms (Isaeva, 2011), including the principle of gender equality. At last, a substantial influence causes the factor of so-called semi-official fusion of government ideology with the religious one (including orthodoxy and Islam), where woman's predestination is initially subordinate.

Sociological analysis of modern citizenships and political stances of Russian men and women, their social and political views and preferences shows multiple and often considerable "gender gap" between them.

Thus the level of electoral activity among women comparing with men is a little higher- $68 \%$ for women and $58 \%$ for men (at Russian legislative elections in December, 2007), 66 and 62\% (at Russian legislative elections in 2011). For the upcoming parliamentary and presidential elections $39 \%(46 \%)$ of men and $53 \%(60 \%)$ of women confirmed their participation as voters.

Meanwhile women more often than men voted for the party in power both at the parliamentary and presidential elections.

At the same time according to public opinion polls $44 \%$ of men and $29 \%$ of women are interested in politics. $54 \%$ of the "first sex" and $61 \%$ of the "second sex" are not engaged in social activities, 79 and $91 \%$ respectively don't participate in political forms of civil activity.

A substantial number of citizens (Grebennikov et al., 2013) don't admit active political parties as theirs (45\% of men and $32 \%$ of women).

The gender structure of the participants at the mass rally "For Fair Elections" (December 24, 2011) was also differentiated: $60 \%$ of men and $40 \%$ of women.

The cited data confirm firstly dependence of men and women from traditional orders that show proper character of their positioning which is determined by the gender display, secondly, less willingness of the "second sex" for political action, thirdly, skillful (technological) usage of these characteristics by the active power for adoption and re-adoption of authoritative order (Zucca, 2008) (which however demonstrates workmanship).

\section{Conclusion}

In concluding remarks of the United Nations Committee on the Elimination of the Discrimination Against Women there is a constant concern over minor representation of Russian women in power structures according to examination of periodical reports on implementation of Convention on the Elimination of all Forms of Discrimination Against Women. 
We can just hope that the Russian "harvest" of political emancipation will ripen, it will be "watered" and "fanned" by contemporary and actual information flows and provide "seeds" for progressive evolution of political gender on the basis of gradual equating of relevant opportunities of men and women.

We also suppose that in the given context improvement of Russian electoral and administrative legislation will appear to be one of the crucial factors.

\section{Acknowledgement}

The article is prepared as a part of the research project implemented with the financial support of the Ministry of Education and Science of the Russian Federation and devoted to the "Legal, Social and Political aspects of Civic Engagement in Russia".

\section{Author's Contributions}

All authors equally contributed in this work.

\section{Ethics}

This article is original and contains unpublished material. The corresponding author confirms that all of the other authors have read and approved the manuscript and no ethical issues involved.

\section{References}

Ayvazova, S.G., 2004. Gender characteristic of authority in contemporary Russia, to the statement of the problem. Politicheskaya Nauka, 1: 170-170.

Bryson, V., 2007. Gender and the Politics of Time: Feminist Theory and Contemporary Debates. 1st Edn., Policy Press, Bristol, ISBN-10: 1861347499, pp: 222.

Bryson, V., 2007. Gender and the Politics of Time: Feminist Theory and Contemporary Debates. 1st Edn., Policy Press, Bristol, ISBN-10: 1861347499, pp: 222.

Connell, R., 1987. Gender and Power: Society, the Person and Sexual Politics, 1st Edn., Stanford University Press, ISBN-10: 0804714304, pp: 352.
Franceschet, S., M.L. Krook and J.M. Piscopo, 2012. The Impact of Gender Quotas. 1st Edn., Oxford University Press, Oxford, ISBN-10: 0199830096, pp: 256.

Gender Issues in Russia, 2004. Adapted from national publications of 1993-2003: 132.

Georgina, W., 2013. The Oxford Handbook of Gender and Politics. 1st Edn., Oxford University Press, ISBN-10: 0199751455, pp: 872.

Golod, S.I., 2008. Sociological and demographic analysis of family states and evolutions. Sotsiologicheskie Issledovaniya, 1: 41-41.

Grebennikov, V.V., N.N. Marchuk and A.A. Galushkin, 2013. Organizational and legal bases of the nationality institute and its place in the system of rights in Russia. World Applied Sci. J., 23: 1217-1220. DOI: 10.5829/idosi.wasj.2013.23.09.438

Isaeva, E.A., 2011. Gender component of the social policy of the EU: Legislator's ideas and legal practitioner's interpretation, Sotsialnoyuridicheskaya Tetra, 1: 125-139.

Loshakova, Y.P., 2013. Regional Peculiarities of Gender Inequality, Sotsiologicheskie Issledovaniya, 5: 135-136.

Rainbow, M., 2010. Parties, Gender Quotas and Candidate Selection in France. 1st Edn., Palgrave Macmillan, Basingstoke, ISBN-10: 0230242537, pp: 224.

Sangadzhiev, B.V., N.N. Marchuk and A.A. Galushkin, 2013. Questions of fair justice and judicial authority functioning in Russian Federation. World Applied Sci. J., 28: 920-923.

DOI: 10.5829/idosi.wasj.2013.28.07.2046

Simone de Beauvoir, 1949. Le Deuxiemesexe, 1st Edn., Knopf Doubleday Publishing Group, New York, ISBN-10: 030781453X, pp: 832.

Tarusina, N.N., 2014. Family law: Accompanied with sovereignty and judicial discretion.

Zucca, L., 2008. Conflicts of fundamental rights as constitutional dilemmas. Social Science Electronic Publishing. 